Western North American Naturalist 67(3), ㄷ 2007, pp. 429-438

\title{
PRESENT EFFECTS OF PAST WILDFIRES ON THE DIETS OF STREAM FISH
}

\author{
Peter Koetsier ${ }^{1,2}$, Quenton Tuckett ${ }^{1}$, and Joshua White ${ }^{1}$
}

\begin{abstract}
Aвstract.-We investigated present indirect effects from a decade-old burn on the diets of stream fish. Based on soil instability and burn patterns from a 12-14-year-old wildfire complex, we separated 9 streams into 3 conditions: unburned, burned, and burned/scoured (i.e., experiencing a massive scour event 1 year post-burn). In the streams, we measured light levels and water temperatures, and we estimated fish density and biomass. We removed the digestive tracts from 9-15 rainbow trout (Oncorhynchus mykiss) from each stream and used a gravimetric procedure to analyze gut contents. Canopy cover development may dictate the composition of dietary items. Greater amounts of aquatic invertebrates and inorganic material were found in trout from streams with reduced overhead canopy. Further, these streams had lower amounts of terrestrial invertebrates and organic materials in the diets of fish. Although trout abundance was not different among the stream treatments, fire-induced, indirect effects on fish diets were still evident more than a decade after the burn. This suggests that recovery rates for trout assemblages may take longer than predicted and may depend on riparian recovery.
\end{abstract}

Key words: wildfire, rainbow trout, diet composition, riparian canopy, streams.

Stream ecosystems are intimately tied to the catchments they drain (Hynes 1975, Vannote et al. 1980). Any disturbance in the catchment can influence the structure and function of the stream's biotic components. For example, clearing of forested and riparian areas can directly affect fish assemblages by increasing stream temperatures and discharge (Hetrick et al. 1998b). Indirectly, reduction of terrestrial vegetation may alter in-stream cover by reducing inputs of large woody debris, and by potentially altering the prey base (Hetrick et al. 1998a, Keith et al. 1998).

In the western United States, wildfire is a commonly occurring landscape-level disturbance which has pronounced effects on both terrestrial and aquatic systems. Immediate effects of fire on stream ecosystems have been well documented (Minshall et al. 1989, 2004, Gresswell 1999, Benda et al. 2003, Robinson et al. 2005), but these effects usually wane within a decade (Gresswell 1999, Minshall et al. 2004). Wildfire's indirect impacts on the stream, usually mediated through changes in terrestrial vegetation, have been less studied. By removing streamside vegetation, fire may influence fish and invertebrates not only by raising water temperatures and escalating substrate scouring, but also by decreasing trans- ported organic material and increasing the importance of autotrophic energy pathways (Minshall et al. 1989, McIntyre and Minshall 1996, Rieman and Clayton 1997).

In landscapes where wildfire is a reccurring disturbance, fish populations tend to recover quickly (Rinne 1996, Rieman et al. 1997, Gresswell 1999). These populations can evolve strategies that incorporate the fire regime into their overall life histories (Reiman and Clayton 1997). Thus, the effect of wildfire on some fish populations may be evident for only a short time (Rinne 1996, Gresswell 1999). However, recent studies suggest that indirect effects, which are more subtle and longer-lasting, can occur between a catchment's terrestrial vegetation and the stream that drains it (e.g., Nakano et al. 1999, Fausch et al. 2002, Dunham et al. 2007). In the long term (tens to hundreds of years), the response of the stream system to fire may be tied to the recovery of the riparian vegetation (Minshall et al. 1989, 2004). While fish assemblages tend to recover quickly, do wildfires still influence fish ecology a decade after the burn? Diet composition in fish may be 1 variable that displays lasting effects due to fire. The diets of fish (hereafter "fish diets") are, in part, linked to the riparian canopy (Wootton 1992, Gerking 1994), and wildfire has

${ }^{1}$ Department of Biology, Boise State University, 1910 University Dr., Boise, ID 83725-1515.

${ }^{2}$ E-mail: pkoet@boisestate.edu 
TABLE 1. Physical characteristics of the 9 streams sampled during July 2005

\begin{tabular}{|c|c|c|c|c|c|c|c|}
\hline Stream/condition & Order & $\begin{array}{l}\text { Elevation } \\
(\mathrm{m})\end{array}$ & $\begin{array}{l}\text { Mean } \\
\text { width } \\
(\mathrm{m})\end{array}$ & $\begin{array}{l}\text { Gradient } \\
(\%)\end{array}$ & $\begin{array}{c}\text { Catchment } \\
\text { area } \\
\left(\mathrm{km}^{2}\right)\end{array}$ & $\begin{array}{l}\text { Discharge } \\
\left(\mathrm{m}^{3} \cdot \mathrm{s}^{-1}\right)\end{array}$ & $\begin{array}{c}\text { Location } \\
\text { (latitude, longitude) }\end{array}$ \\
\hline \multicolumn{8}{|l|}{ Burned/scoured } \\
\hline SF Sheep Creek & 2 & 1137 & 4.2 & 2.8 & 31.7 & 0.19 & $43^{\circ} 40^{\prime} 926^{\prime \prime} \mathrm{N}, 115^{\circ} 38^{\prime} 811^{\prime \prime} \mathrm{W}$ \\
\hline Trapper Creek & 3 & 1479 & 2.6 & 4.7 & 9.1 & 0.06 & $43^{\circ} 53^{\prime} 543^{\prime \prime} \mathrm{N}, 115^{\circ} 26^{\prime} 918^{\prime \prime} \mathrm{W}$ \\
\hline Wren Creek & 3 & 1363 & 2.4 & 10.2 & 9.4 & 0.29 & $43^{\circ} 52^{\prime} 435^{\prime \prime} \mathrm{N}, 115^{\circ} 30^{\prime} 990^{\prime \prime} \mathrm{W}$ \\
\hline \multicolumn{8}{|l|}{ Burned } \\
\hline Cottonwood Creek & 3 & 1296 & 3.0 & 4.5 & 24.1 & 0.19 & $43^{\circ} 40^{\prime} 538^{\prime \prime} \mathrm{N}, 115^{\circ} 49^{\prime} 417^{\prime \prime} \mathrm{W}$ \\
\hline Hungarian Creek & 3 & 1286 & 1.8 & 6.4 & 11.5 & 0.07 & $43^{\circ} 49^{\prime} 039^{\prime \prime} \mathrm{N}, 115^{\circ} 32^{\prime} 127^{\prime \prime} \mathrm{W}$ \\
\hline Lost Creek & 2 & 1368 & 3.3 & 5.3 & 14.4 & 0.05 & $43^{\circ} 51^{\prime} 586^{\prime \prime} \mathrm{N}, 115^{\circ} 31^{\prime} 737^{\prime \prime} \mathrm{W}$ \\
\hline \multicolumn{8}{|l|}{ Unburned } \\
\hline Beaver Creek & 2 & 1332 & 1.9 & 4.6 & 14.2 & 0.05 & $43^{\circ} 53^{\prime} 186^{\prime \prime} \mathrm{N}, 115^{\circ} 30^{\prime} 564^{\prime \prime} \mathrm{W}$ \\
\hline Lost Man Creek & 2 & 1599 & 2.7 & 2.1 & 13.3 & 0.07 & $43^{\circ} 44^{\prime} 971^{\prime \prime} \mathrm{N}, 115^{\circ} 26^{\prime} 264^{\prime \prime} \mathrm{W}$ \\
\hline Trail 2 Creek & 2 & 1559 & 2.2 & 4.1 & 17.2 & 0.06 & $43^{\circ} 45^{\prime} 623^{\prime \prime} \mathrm{N}, 115^{\circ} 08^{\prime} 881^{\prime \prime} \mathrm{W}$ \\
\hline
\end{tabular}

long-term impacts on the recovery of that canopy. Based on these relationships, we hypothesized that fire-induced change that alters riparian vegetation should be expressed in the diet composition of stream fish. We collected fish from unburned streams and streams burned in 1992-1994. We compared fish stomach contents using gravimetric procedures, and found differences in gut content items that were correlated to fire-altered riparian vegetation.

\section{Study AREA}

Our study was conducted on nine 2nd- and 3rd-order tributaries of the Boise River catchment, located in the southern forested subregion of the Idaho batholith ecoregion $\left(44^{\circ} 10^{\prime} \mathrm{N}-\right.$ $\left.44^{\circ} 20^{\prime} \mathrm{N}, 115^{\circ} 30^{\prime} \mathrm{W}\right)$. Catchments in the Boise River Basin, located in the Boise National Forest, have hillside gradients ranging from $20^{\circ}$ to $40^{\circ}$ and are highly dissected. Upland vegetation is dominated by stands of ponderosa pine (Pinus ponderosa) and Douglas-fir (Pseudotsuga menziesii), while riparian vegetation is dominated by willow (Salix spp.), cottonwood (Populus spp.), and water birch (Betula occidentalis), each type with an associated understory of mixed shrubs, grasses, and forbs. The regional climate is continental with an average precipitation of $500 \mathrm{~mm}$ per year (Benda et al. 2003). The bedrock substrate in the basin is dominated by moderate to well-weathered coarse-grained quartz monzonite typical of much of the Idaho batholith. Soils are lithosols with weakly developed A horizons ranging from 5 to $25 \mathrm{~cm}$ thick (Megahan and Ketche- son 1996). These granitic, droughty soils have limited fertility and are highly erodible when vegetation is removed (McGarth et al. 2001).

\section{Methods}

This research was part of ongoing investigation examining the effects of wildfire on stream trophic structure. Our present study was conducted from 7 July through 20 July 2005. Using aerial photographs, GIS layer maps, and considering a stream fire study design developed by the USDA FS Rocky Mountain Research Station (see Dunham et al. 2007), we tried to choose streams for which we could match catchment area, slope, gradient, elevation, and discharge (Table 1). Of the 9 study streams, 6 were burned in the 1992-1994 Foothills fire and Idaho City complex of wildfires $85 \%-100 \%$ of catchment; Dunham et al. 2007). Due to soil instability after vegetation removal, 3 of these burned systems experienced a massive scouring (erosion and redeposition of bed material throughout the stream's reach) the following year. Subsequently, these 3 streams continued to experience moderate scour and redeposition of bed material after minor storms. Following Dunham et al. (2007), we grouped the study streams into 3 conditions based on wildfire patterns and soil instability. These stream conditions were (1) unburned: streams that were not burned by the fires; (2) burned: streams that burned above ground but retained much of the belowground vegetative structures; and (3) burned/scoured: streams that, less than a year after the fire, experienced major erosion, movement, and deposition of 
bed material, which removed most of the riparian belowground vegetative structures (see Benda et al. 2003 and Dunham et al. 2007 for fire history of this area).

We used the amount of light potentially penetrating the riparian vegetation and reaching the stream's surface as a proximate measure of riparian development. After walking along 1-2 km of each stream, we chose a 100$\mathrm{m}$ segment as a representative reach. To estimate riparian canopy, we randomly chose 50 points along and across the $100-\mathrm{m}$ reach in each stream. At each point, we measured the amount of photosynthetically active radiation (PAR) using a LI-COR quantum sensor (model LI-192SA) and a LI-COR light meter (model LI-250). We placed the sensor $3 \mathrm{~cm}$ above the water's surface and measured PAR on cloudless days between 1200 hours and 1300 hours. We measured stream discharge by subdividing the cross section of each stream channel into 15 sections. In each section, a single flow measurement was made at 6/10 depth below the water's surface. Discharge equaled the sum of the volume of water flowing through the area of each individual section per unit time (Gordon et al. 2004). Once PAR and discharge were measured, we placed a temperature data logger in the stream and recorded water temperature every 30 minutes over a 48 -hour period.

Fish assemblages in the tributaries of the upper Boise River catchment are comprised of rainbow trout (Oncorhynchus mykiss), brook trout (Salvelinus fontinalis), and bull trout (S. confluentus), mountain whitefish (Prosopium williamsoni), and shorthead sculpin (Cottus confuses). However, 98\% of the fishes collected in the study streams were O. mykiss. Consequently, we limited our study of fish variables and gut content comparisons to this species. We sampled O. mykiss by backpack electrofishing immediately after we measured PAR and discharge. Block nets (mesh size: 5 $\mathrm{mm}$ ) were set at the upstream and downstream ends of the sampling segment. Two sequential passes were made (in all streams, probability of fish capture equaled or exceeded 0.80 , necessitating only 2 passes; Armour et al. 1983). We estimated fish density using a standard depletion-curve method (Youngs and Robson 1978, Armour et al. 1983, Brower et al. 1997). All O. mykiss collected were identified and weighed, and the total lengths were recorded. Because we collected no young-of-the-year from 1 of the burned/scoured streams, we omitted all individuals $<70 \mathrm{~mm}$ from this study. Of the fishes collected, we removed the digestive tracts from 9-15 fish from each stream and stored them on ice for transport back to the laboratory.

In the laboratory, we dissected each digestive tract and removed the contents. With the aid of a dissecting microscope, we separated gut contents into 4 categories: aquatic invertebrates, terrestrial invertebrates, organic material (leaf and bark particles, algae, etc.), and inorganic matter (sand, small pebbles, etc.). We identified invertebrates to family, but in most cases we could also recognize genera. All stomachs that we examined contained material that could be placed in 1 (or more) of our gut content categories; no empty stomachs were encountered. Once stomach contents were removed, identified, and sorted into categories, the materials were oven-dried for 2 days at $80^{\circ} \mathrm{C}$ to stabilize their weights and to decrease sample variability (Hyslop 1980, Bowen 1996), and then the samples were weighed. Additionally, we estimated the condition coefficient of $O$. mykiss collected in each stream using the following equation (Everhart and Young 1981):

$$
\mathrm{C}=\left(\mathrm{W} / \mathrm{L}^{3}\right) \times 10^{5},
$$

where $\mathrm{C}=$ condition coefficient, $\mathrm{W}=$ fish biomass $(\mathrm{g})$, and $\mathrm{L}=$ fish length $(\mathrm{mm})$.

To determine PAR and water temperature differences among our 3 stream conditions, we analyzed the data using an analysis of variance (ANOVA) with stream condition as the treatment and PAR or temperature as response variables. These datasets were $\log (\mathrm{x}+1)$-transformed to achieve linearity and homoscedasticity. We also used ANOVA to identify differences in fish density, total length, biomass, and condition among the stream conditions. Because each of our gut content categories was recorded as a percentage of the sample's total weight, we applied an arcsine transformation to the data to normalize their distribution (Zar 1999). We used the nonparametric Kruskal-Wallis ANOVA (Siegel and Castellan 1988) to determine if stream condition affected the percent composition of fish diet. If significance was found $(P<0.05)$, we then used a 2 sample Kolmogorov-Smirnov test as a post hoc 
TABLE 2. One-way ANOVA source table for water temperature and photosynthetically active radiation (PAR) measured in the study streams.

\begin{tabular}{|c|c|c|c|c|c|}
\hline Source & df & SS & MS & $F$-ratio & $P$ \\
\hline Temperature & 8 & 2.15 & 0.27 & 50.42 & $<0.0001$ \\
\hline Error & 432 & 2.31 & 0.01 & & \\
\hline Total & 440 & 4.45 & & & \\
\hline PAR & 8 & 122.22 & 15.28 & 36.07 & $<0.0001$ \\
\hline Error & 441 & 186.77 & 0.42 & & \\
\hline Total & 449 & 308.98 & & & \\
\hline
\end{tabular}

pairwise comparison between the stream conditions within that gut content category (Siegel and Castellan 1988).

\section{RESUlTs}

Noticeable visual differences in riparian canopy were evident between the 3 stream conditions. These field observations were confirmed by significant differences in both photosynthetically active radiation (PAR) measured at the streams' surface $\left(\mathrm{F}_{2,441}=36.07\right.$, $P<0.001)$ and by stream water temperatures $\left(\mathrm{F}_{2,432}=50.41, P<0.001\right.$; Table 2). Our burned/scoured streams had the highest mean values for PAR $\left(1200 \mu \mathrm{mol} \cdot \mathrm{m}^{-2} \mathrm{~s}^{-1}\right)$ and water temperature $\left(16.3^{\circ} \mathrm{C}\right)$. Measurements for these variables were significantly greater $(P<0.05)$ than those recorded in our unburned streams (PAR $292 \mu \mathrm{mol} \cdot \mathrm{m}^{-2} \mathrm{~s}^{-1}$; temperature $11.6^{\circ} \mathrm{C}$ ). For both PAR and water temperature, the burned streams were intermediate between the other conditions (Fig. 1).

Average O. mykiss density was highest in burned streams (density $=34$ individuals . $\left.100 \mathrm{~m}^{-2}, s_{\bar{x}}=4.0\right)$ while density was the lowest in burned/scoured streams $(\bar{x}=18$ individuals $\left.\cdot 100 \mathrm{~m}^{-2}, s_{\bar{x}}=0.4\right)$; however, these differences were not significant $\left(\mathrm{F}_{2,6}=1.14\right.$, $P=0.38$ ). Significant differences did occur in fish total length and biomass among the stream conditions (Fig. 2). Mean total length and biomass were largest in the burned streams, but smallest in the unburned ones (total length: $\mathrm{F}_{2,6}=3.47, P=0.04$; biomass: $\left.\mathrm{F}_{2,6}=3.07, P=0.05\right)$. Regardless of differences in fish length and biomass, fish condition was nearly equal in all 3 stream conditions $\left(\mathrm{F}_{2,6}=2.01, P=0.14\right)$.

Gravimetric comparisons of gut contents did show significant differences among the 3 designated stream conditions (Fig. 3). Both aquatic invertebrate (Kruskal-Wallis ANOVA:
$H=6.04, P=0.049)$ and inorganic matter (Kruskal-Wallis ANOVA: 6.36, $P=0.04$ ) categories displayed the same trend, with proportionately more of these materials ingested by fish in the burned/scoured streams than in either of the other 2 stream conditions. Although aquatic invertebrates were highest in O. mykiss guts collected from the burned/ scoured streams, these values did not vary significantly from values for guts collected from the burned systems $(P=0.37)$, but both were greater than the values for trout guts collected from unburned streams $(P<0.05)$. Likewise, trout from burned/scoured systems had a higher proportion of ingested inorganic matter in their stomachs than trout in the other streams $(P<0.04)$, while material from fish in the burned and unburned streams was not significantly different.

In contrast, the organic material category displayed an opposite trend, with more material ingested by O. mykiss from the unburned streams when compared to the other streams, with the least organic material in fish from the burned/scoured systems (Kruskal-Wallis ANOVA: $H=9.29, P=0.01)$. Material in the organic category consisted of leaf and bark particles as well as some algae (frequently occurring in stomachs from fish in the burned/ scoured systems). There were no proportionate differences of organic material in trout among the burned and unburned conditions, but each was significantly greater than that found in fish from the burned/scoured streams $(P<0.04)$. Although the terrestrial invertebrate category showed the same pattern as that of organic material, the pattern was not significant.

\section{Discussion}

The immediate effects of wildfire on stream biotic structure and function have been well documented (Minshall et al. 1989, Minshall 

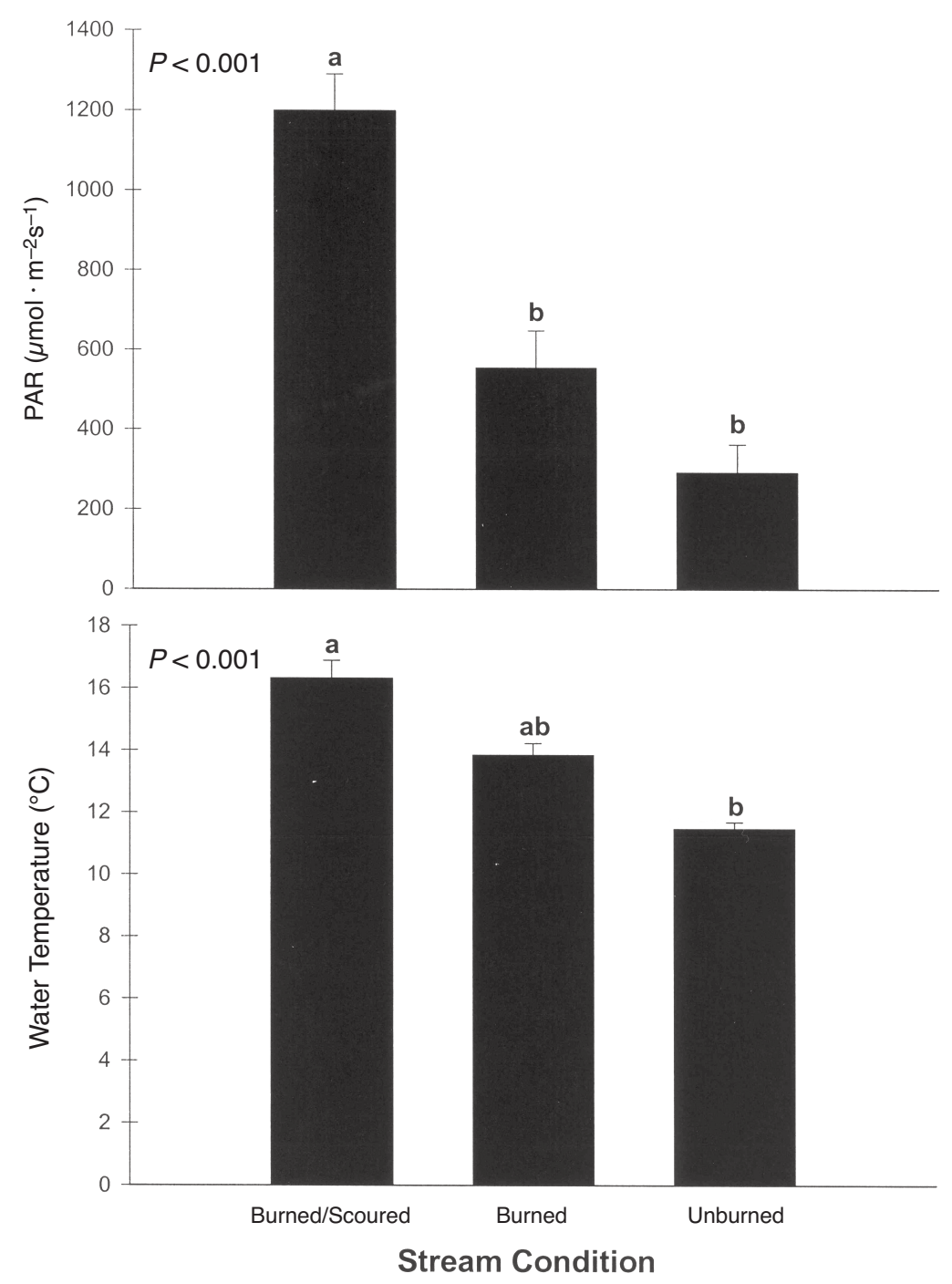

Fig. 1. Mean levels of photosynthetically active radiation (PAR) and water temperatures measured in the 3 stream conditions during July 2005. Same letters indicate no significant difference (Tukey post hoc pairwise comparisons; $P>$ 0.05). Bars represent 1 standard error.

and Brock 1991, Rinne 1996, Rieman and Clayton 1997, Gresswell 1999, Spencer et al. 2003). Less clear are the mid- to long-term patterns in biotic response (but see Robinson et al. 2005 and Dunham et al. 2007 for physical data). At the community level, biotic variables have shown large variation with little correlation to predicted response signatures (Minshall et al. 2004). For example, fish abundance and community structure were predicted to attain preburn densities 10-12 years after the fire (Minshall et al. 1989, Gresswell 1999). But fish assemblages in streams of the
Boise River Basin have returned to prefire numbers within 3 years post-burn (Rieman and Clayton 1997, Rieman et al. 1997). Lack of correlation to predicted patterns and wide variation have led some to suggest that studying population-level responses might be more appropriate for detecting long-term change and recovery (Mihuc 2004, Mihuc and Minshall 2005).

Though we found no differences in rainbow trout population densities or fish condition among the study streams, our results do suggest that wildfire continues to affect biotic 

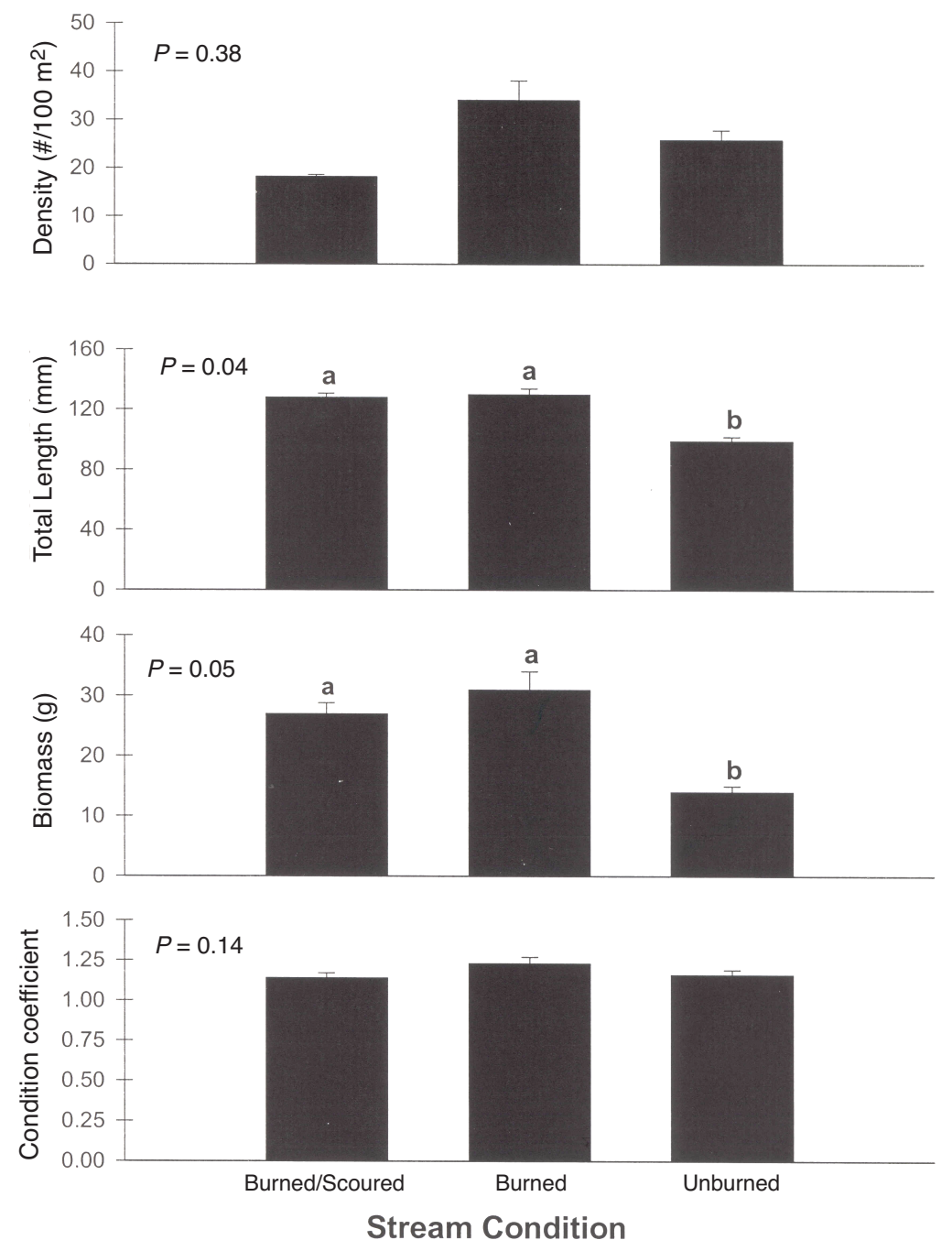

Fig. 2. Mean density, mean total length, mean weight, and condition factor of Oncorhynchus mykiss collected from stream treatments during July 2005. Same letters indicate no significant difference (Tukey post hoc pairwise comparisons; $P>0.05)$. Bars represent 1 standard error.

processes in the long-term, albeit indirectly, through alterations of the riparian canopy cover. While trout densities were not different among our streams, we did find significant differences in the gravimetric comparisons of fish stomach contents. Fish diet appears to be influenced by the rate of riparian recovery. Due to a lack of vegetative overhang in our burned/scoured systems, fewer terrestrial invertebrates may have fallen into these streams. As a result, aquatic invertebrates made up a large portion of the fish diet. During the process of feeding on the benthic fauna, fish may have engulfed sand and small stones from the substrate itself. Inorganic materials from ingested case-dwelling invertebrates were also present in fish from this stream condition. We found several intact cases from the caddis larvae Dicosmoecus within fish stomachs from the burned/scoured streams. Indeed, inorganic material was significantly greater in fish stomachs from the burned/scoured streams when compared to fish stomachs from the other 2 stream conditions. Others have interpreted the presence of organic and inorganic matter in salmonid gut analyses as material that was 


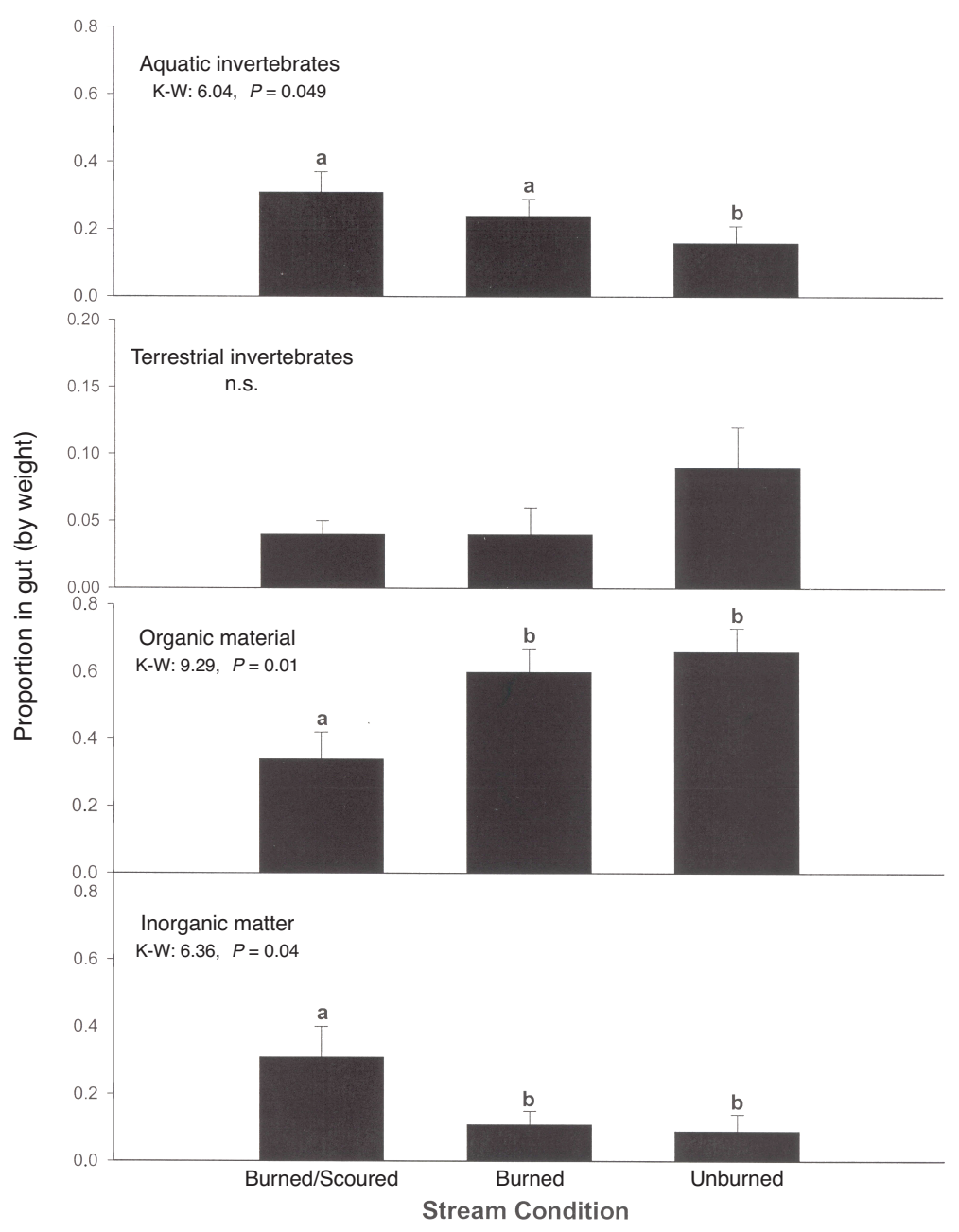

Fig. 3. Mean proportion (by weight) of material found in the 4 categories of gut contents sampled from fish collected in the 3 different stream conditions during July 2005. K-W = Kruskal-Wallis test statistic, n.s. = no significant difference. Same letters indicate no significant difference (Kolmogorov-Smirnov post hoc pairwise comparisons; $P>0.05$ ). Bars represent 1 standard error.

ingested accidentally during epibenthic feeding (Tippets and Moyle 1978, Angradi and Griffith 1989).

The opposite was true of fish from the unburned systems. With a thick overhanging canopy present, the input of terrestrial invertebrates into these streams may have been high. In addition, the thick canopy cover reduced the amount of solar radiation available to the primary producers of unburned streams, potentially limiting the amount of autotrophic energy available to the aquatic invertebrate community (Minshall and Brock 1991, Minshall 2003). The combination of these 2 factors may result in a larger percentage of terrestrial insects found in the stomachs of fish from the unburned sites. In feeding on the terrestrially-derived invertebrates, fish may ingest plant material as well. We found higher amounts of organic matter in the stomachs of trout from these unburned streams. Most of this material was composed of leaf, needle, and bark particles. Vascular plant material may supplement the energy requirements of some fish (Bowen et al. 1995), but it is likely that this material was accidentally ingested during water-column feeding.

Our study supports some of the predictions originally made by Minshall et al. (1989) immediately after the 1988 Yellowstone fires. 
The return of stream ecosystems to prefire levels of structure and function appear to be closely tied to the recovery of the catchment's forest and understory vegetation (Rieman and Clayton 1997). The highly erodible nature of the granitic soils (common to the Idaho batholith region) underlying our streams coupled with fire intensity dictate the recovery time of the catchment's vegetation. Within 1 or 2 years after the fires, some of the study streams experienced a massive scouring, erosion, and redeposition of bed materials (Benda et al. 2003), removing much of the belowground vegetative structures. Consequently, streams like these may be prone to substrate-scouring events at moderate levels of precipitation (Megahan 1983, Megahan and Ketcheson 1996). In turn, this continued scouring could further delay riparian recovery. By using the amount of solar radiation reaching the water's surface as a proxy for canopy coverage, we concluded that the riparian vegetation for the burned/scoured streams (when compared to the unburned ones) had not yet attained prefire levels 12-14 years after the burn. The sparse amounts of riparian overhang directly affected stream water temperatures (Minshall et al. 1989, 2004, Dunham et al. 2007). In turn, many biotic components of stream ecosystems-algal standing crop, invertebrate growth rates and community composition, fish growth and production-are partially governed by water temperature (Allan 1995, Giller and Malmqvist 1998). Indeed, in 1 of the burned/scoured streams (Wren Creek) we found no young-of-the-year of any fish species. Thus, long-term, indirect effects of the 1992-1994 wildfires may be evident in other biotic parameters within these streams.

The intensity of the fire coupled with vegetation removal and the resulting soil instability may alter the recovery trajectory of the burned/scoured streams (sensu Drake 1990). Streams with eroded catchments and severe streambed scour may experience prolonged recovery times, or they may move to a new steady-state final configuration (Matthaei et al. 2004). In severe disturbance regimes, such as repeated scouring of the stream channel over a long time period, new lower levels of biotic richness and abundance may be established (Minshall et al. 1989).

In conclusion, wildfire may have subtle, long-lasting effects on the functioning of stream ecosystems. The duration of these effects are dependent upon riparian recovery and soil stability. Too often, studies of stream catchments in fire-prone basins are classified as only burned or unburned, leading to a wide variation in long-term response signatures (e.g., Robinson et al. 2005). Our study supports the notion that a 3rd category, burned/scoured streams, should be considered based on catchment soil types, channel scouring frequency, and riparian vegetation recovery. Identifying the type and frequency of post-fire disturbance (sensu Lake 2000) may reduce the variation evident in long-term fire recovery studies and lead to a better understanding of wildfire's effects on long-term stream dynamics.

\section{ACKNOWLEDGMENTS}

This study was supported by the National Research Initiative of the USDA Cooperative State Research, Education and Extension Service, grant number 2003-35101-13682, and by the Dan Montgomery Foundation for ecological study. We would also like to thank C. Valdivia, T. Krause, and A. Fonner for field and laboratory assistance; D. Nagel (USDA Forest Service) for GIS layer maps; and A. Rosenberger (USDA Forest Service) and J. Dunham (USDA Forest Service / USGS) for many thoughtful discussions on study site selection and the role of fire in forested ecosystems.

\section{Literature Cited}

ALLAN, J.D. 1995. Stream ecology: structure and functioning of running waters. Chapman and Hall. New York. 388 pp.

ANGRADI, T.R., AND J.S. GRIFFITH. 1989. Diel feeding chronology and diet selection of rainbow trout (Oncorhynchus mykiss) in the Henry's Fork of the Snake River, Idaho. Canadian Journal of Fisheries and Aquatic Sciences 47:199-209.

Armour, C.L., K.P. Burnham, and W.S. Platts. 1983. Field methods and statistical analyses for monitoring small salmonid streams. FWS/OBS-83/33, Western energy and land use team. U.S. Fish and Wildlife Service, Fort Collins, CO. 200 pp.

Benda, L., D. Miller, P. Bigelow, And K. Andras. 2003. Effects of post-wildfire erosion on channel environments, Boise River, Idaho. Forest Ecology and Management 178:105-119.

Bowen, S.H. 1996. Quantitative description of diet. Pages 513-532 in B.R. Murphy and D.W. Willis, editors, Fisheries techniques. 2nd edition. American Fisheries Society, Bethesda, MD.

Bowen, S.H., E.V. LuTz, And M.O. AhLgRen. 1995. Dietary protein and energy as determinants of food quality: trophic strategies compared. Ecology 76:899-925. 
Brower, J.E., J.H. Zar, and C.N. von Ende. 1997. Field and laboratory methods for general ecology. 4th edition. McGraw-Hill Publishing Company, Boston, MA. $273 \mathrm{pp}$.

DraKe, J.A. 1990. Communities as assembled structures: do rules govern patterns? Trends in Ecology and Evolution 5:159-164.

Dunham, J.B., A.E. Rosenberger, C.H. Luce, and B.E. RIEMAN. 2007. Influences of wildfire and channel reorganization on spatial and temporal variation in stream temperature and the distribution of fish and amphibians. Ecosystems: 10:335-346.

Everhart, W.H., AND W.D. Young. 1981. Principles of fishery science. Cornell University Press, Ithaca, NY. 349 pp.

Fausch, K.D., M.E. Power, and M. Murakami. 2002. Linkages between stream and forest food webs: Shigeru Nakano's legacy for ecology in Japan. Trends in Ecology and Evolution 17:429-434.

Gerking, S.D. 1994. Feeding ecology of fish. Academic Press, San Diego, CA. 416 pp.

GILler, P.S., AND B. MalmQvist. 1998. The biology of streams and rivers. Oxford University Press, Oxford, U.K. 296 pp.

Gordon, N.D., T.A. McMahon, B.L. Finlayson, C.J. GipPEL, AND R.J. NATHAn. 2004. Stream hydrology: an introduction for ecologists. 2nd edition. John Wiley \& Sons, Ltd., West Sussex, England. 429 pp.

Gresswell, R.E. 1999. Fire and aquatic ecosystems in forested biomes of North America. Transactions of the American Fisheries Society 128:193-221.

Hetrick, N.J., M.A. Brusven, T.C. Bjornn, R.M. Keith, AND W.R. MEEHAN. 1998a. Effects of canopy removal on invertebrates and diet of juvenile Coho salmon in a small stream in southeast Alaska. Transactions of the American Fisheries Society 127:876-888.

Hetrick, N.J., M.A. Brusven, W.R. Meehan, and T.C. BJoRnN. 1998b. Changes in solar input, water temperature, periphyton accumulation, and allochthonous input and storage after canopy removal along two small salmon streams in southeast Alaska. Transactions of the American Fisheries Society 127:859875 .

Hynes, H.B.N. 1975. The stream and its valley. Internationale Vereinigung für theoretische und angewandte Limnologie 19:1-15.

HysLop, E.J. 1980. Stomach contents analysis-a review of methods and their application. Journal of Fish Biology 17:411-429.

Keith, R.M., T.C. Bjornn, W.R. Meehan, N.J. Hetrick, And M.A. BRusven. 1998. Response of juvenile salmonids to riparian and instream cover modifications in small streams flowing through second-growth forests of southeast Alaska. Transactions of the American Fisheries Society 127:889-907.

LAKE, P.S. 2000. Disturbance, patchiness, and diversity in streams. Journal of the North American Benthological Society 19:573-592.

Matthaei, C.D., C.R. Townsend, C.J. Arbuckle, K.A. Peacock, C. Guggelberger, C.E. Küster, and H. HuBER. 2004. Disturbance, assembly rules, and benthic communities in running waters: a review and some implications for restoration projects. Pages 367-388 in V.M. Temperton, R.J. Hobbs, T. Nuttle, and S. Halle, editors, Assembly rules and restoration ecology: bridging the gap between theory and practice. Island Press, Washington, DC.
McGarth, C.L., A.J. Woods, J.M. Omernick, S.A. Bryce, M. Edmundson, J.A. Nesser, J. Shelden, et Al. 2001. Ecoregions of Idaho. U.S. Geological Survey, Reston, VA.

McIntyre, M.J., And G.W. Minshall. 1996. Changes in transport and retention of course particulate organic matter in streams subjected to fire. Pages 59-76 in J. Greenlee, editor, The ecological implications of fire in Greater Yellowstone: proceedings of the Second Biennial Conference of the Greater Yellowstone Ecosystem. International Association of Wildland Fire, Fairfield, WA.

Megahan, W.F. 1983. Hydrologic effects of clearcutting and wildfire on steep granitic slopes in Idaho. Water Resources Research 19:811-819.

Megahan, W.F., and G.L. Ketcheson. 1996. Predicting downslope travel of granitic sediments from forest roads in Idaho. Water Resources Bulletin 32:371-382.

Minuc, T.B. 2004. Food web dynamics in Yellowstone streams: shifts in the trophic basis of a stream food web after wildfire disturbance. Pages 189-199 in L.L. Wallace, editor, After the fires: the ecology of change in Yellowstone National Park. Yale University Press, New Haven, CT.

Minuc, T.B., and G.W. Minshall. 2005. The trophic basis of reference and post-fire stream food webs 10 years after wildfire in Yellowstone National Park. Aquatic Sciences 67:541-548.

MinshaLL, G.W. 2003. Responses of stream benthic macroinvertebrates to fire. Forest Ecology and Management 178:155-161.

Minshall, G.W., And J.T. BROCK. 1991. Observed and anticipated effects of forest fire on Yellowstone stream ecosystems. Pages 123-135 in R.B. Keiter and M.S. Boyce, editors, The Greater Yellowstone ecosystem: redefining America's wilderness heritage. Yale University Press, New Haven, CT.

Minshall, G.W., J.T. Brock, and J.D. Varley. 1989. Wildfires and Yellowstone's stream ecosystems. Bioscience 39:707-715.

Minshall, G.W., T.V. Royer, and C.T. Robinson. 2004. Stream ecosystem response to fire: the first ten years. Pages 165-188 in L.L. Wallace, editor, After the fires: the ecology of change in Yellowstone National Park. Yale University Press, New Haven, CT.

NaKano, S., H. MiYasaKa, AND N. KuHaRA. 1999. Terrestrialaquatic linkages: riparian arthropod inputs alter trophic cascades in a stream food web. Ecology 80: 2435-2441.

Rieman, B.E., And J. Clayton. 1997. Wildfire and native fish: issues of forest health and conservation of sensitive species. Fisheries 22:6-15.

Rieman, B.E., D. Lee, G. Chandler, and D. Myers. 1997. Does wildfire threaten extinction for salmonids: responses of redband trout and bull trout following recent large fires on the Boise National Forest. Pages 47-57 in J. Greenlee, editor, Proceedings of the symposium on fire effects on threatened and endangered species and habitats. International Association of Wildland Fire, Fairfield, WA.

Rinne, J.N. 1996. Short-term effects of wildfire on fishes and aquatic macroinvertebrates in the southwestern United States. North American Journal of Fisheries Management 16:653-658.

Robinson, C.T., U. Uehlinger, and G.W. Minshall. 2005. Functional characteristics of wilderness streams 
twenty years following wildfire. Western North American Naturalist 65:1-10.

Siegel, S., and N.J. Castellan. 1988. Nonparametric statistics for the behavioral sciences. 2nd edition. McGraw-Hill Publishing Co., New York. 399 pp.

Spencer, C.N., K.O. Gabel, AND F.R. Hauser. 2003. Wildfire effects on food webs and nutrient dynamics in Glacier National Park. Forest Ecology and Management 178:141-153.

TIPPETS, W.E., AND P.B. MoyLe. 1978. Epibenthic feeding by rainbow trout (Salmo gairdneri) in the McCloud River, California. Journal of Animal Ecology 47: 549-559.

Vannote, R.L., G.W. Minshall, K.W. Cummins, J.R. Sedell, AND C.E. Cushing. 1980. The river continuum concept. Canadian Journal of Fisheries and Aquatic Sciences 37:130-137.
Wootton, R.J. 1992. Fish ecology. Chapman and Hall Publishing Co., New York. 212 pp.

Youngs, W.D., AND D.S. Robson. 1978. Estimation of population number and mortality rates. Pages 137-164 in T. Bagenal, editor, Methods for assessment of fish production in fresh waters. 3rd edition. IBP Handbook \#3, Blackwell Scientific Publications, Oxford, U.K.

ZAR, J.H. 1999. Biostatistical analysis. 4th edition. Prentice Hall Publishing Co., Upper Saddle River, NJ. 663 pp.

Received 4 April 2006

Accepted 8 January 2007 